\title{
PERAN STRATEGIS AKTIVIS PEREMPUAN NURUL JANNAH AL FIRDAUS DALAM MEMBENTUK KESADARAN BERAGAMA PEREMPUAN MISKIN KOTA
}

\author{
Hasyim Hasanah \\ Dosen Institut Agama Islam Negeri (IAIN) Wa54lisongo \\ basyimbasanah_82@yahoo.co.id
}

\begin{abstract}
Religious awareness is conscious and recognize the potential, as well as carrying out religious moral values. This is important, because each individual has a duty of chalips that must be directed and developed. Purposes of the study describes the strategic role of women activists Nurul Jannab al-Firdaus in forming religious awareness of poor urban women. This research applying descriptive qualitative with a psychophenomenological approach. The results of research presented the strategic role of women activists Nurul Jannab in forming religious awareness of poor urban women, that is shown by active involvement through mentoring, education, learning, thus growing independence, and awareness in performing religious rituals on poor urban women.
\end{abstract}

Key words: Women Activities, Religious Awareness, Poor Urban Womens

\begin{abstract}
Abstrak
Kesadaran beragama merupakan kondisi sadar dan mengenali potensi, serta melaksanakan nilai-nilai moral agama. Hal ini penting dilakukan karena setiap individu memiliki tugas kekhalifahan yang harus diarabkan dan dikembangkan. Tujuan penelitian mendeskripsikan peran strategis aktivis perempuan Nurul Jannab al-Firdaus dalam membentuk kesadaran beragama perempuan miskin kota. Metode penelitian menggunakan deskriptif kualitatif dengan pendekatan psiko-fenomenologi. Hasil penelitian menunjukkan peran strategis aktivis perempuan Nurul Jannab dalam membentuk kesadaran beragama perempuan miskin kota, yang ditunjukkan dengan keterlibatan aktif melalui pendampingan, pendidikan, pembelajaran, sebingga tumbuh kemandirian, dan dan kesadaran dalam melaksanakan praktik ritual agama pada perempuan miskin perkotaan.
\end{abstract}

Kata kunci: Aktivis Perempuan, Kesadaran Beragama, Perempuan Miskin Kota 


\section{Pendahuluan}

Beragama merupakan hak paling mendasar bagi individu, khususnya untuk mengembangkan dan melaksanakan ajaran agamanya sesuai keyakinan dan kepercayaan, selanjutnya diarahkan untuk mencapai kesejahteraan, kebahagiaan hidup. Salah satu potensi keberagamaan yang menempati posisi penting untuk mewujudkannya adalah kesadaran beragama. Kesadaran beragama merupakan kondisi tau dan mengerti potensi keberagamaan di dalam diri seseorang (Jalaluddin, 2001:122).

kesadaran beragama sebagian orang dapat dikembangkan dan diarahkan secara tepat. tingkat kesadaran beragama pada individu memiliki kadar berbeda (Soedarsono, 2000:31). Kesadaran beragama sebagian besar masyarakat miskin merupakan bentuk menghindarkan diri dari himpitan ekonomi, memberikan rasa aman, tenang, damai dan sejahtera. Kenyataan ini tidak berlaku bagi komunitas perempuan miskin kota Banyumanik, yang memiliki anggapan bahwa agama merupakan lembaga formal yang tidak memiliki makna dan keuntungan bagi kehidupan. Beragama merupakan syarat formal pengakuan identitas sosial masyarakat. Terjadi pemahaman keliru terhadap agama, sehingga timbul kemalasan dan ketidakpedulian terhadap pelaksanaan ajaran agama. Kondisi ini merupakan bentuk ketidaksadaran masyarakat miskin dalam memahami dan menghayati ajaran agama.

Para aktivis perempuan Nurul Jannah secara intens memberikan pelayanan sosial keagamaan yang belum dilakukan aktivis lain maupun pemerintah kota Semarang. Salah satu tema pengembangan dan pemberdayaan perempuan miskin kota yaitu pembentukan kesadaran beragama. Bagi para aktivis, komunitas perempuan miskin yang dibekali dengan kemampuan sadar beragama secara otomatis dapat membentuk keluarga berkualitas, karena dalam sistem sosial keluarga perempuan memainkan peran strategis dalam pendidikan dan pembinaan sikap mental anggota keluarganya. Atas dasar inilah diperlukan upaya mengetahui peran strategis aktivis perempuan Nurul Jannah dalam membentuk kesadaran beragama perempuan miskin kota Banyumanik. 


\section{Teori Kesadaran Beragama}

Alport (1991) dalam Dudley \& Cruise (1999:98) menyebutkan bahwa kesadaran beragama merupakan proses pendewasaan atas pemahaman ajaran agama yang tumbuh sebagai hasil renungan dan perkembangan watak keberagamaan, selanjutnya direnungkan sebagai angan dan perjalanan spiritual. Senada dengan pandangan itu, Wotson (1999:142) menyebutkan bahwa kesadaran beragama merupakan proses akumulasi seluruh pengalaman hidup yang dikenali sebagai refleksi falsafah dan pandangan hidup, sehingga menjadikan seseorang selalu menghadirkan sistem nilai positif sesuai ajaran agama (Nashori, 2000:18; Jalaluddin, 2007:123). Dari beberapa pengertian itu dapat disimpulkan bahwa kesadaran beragama merupakan suatu kondisi sadar, peduli dan mau tau dengan nilai-nilai luhur agama, diyakini benar dengan mendasarkan pada aspek sistem nilai, sikap dan perilaku, dan diimplementasikan dalam praktik ritualitas ibadah sesuai aturan nilai norma ajaran agama.

\section{Peran aktivis Perempuan dalam mengembangkan kesadaran beragama}

Posisi strategis perempuan dalam pembangunan dapat dilihat dari keterlibatan perempuan dalam gerakan dakwah komunitas. Peta Gerakan dakwah komunitas tertentu menghasilkan transformasi dan rekayasa sosial guna mendukung pengembangan dan pemberdayaan komunitas (Kusmawan, 2009:9; Yakan, 2010:251). Begitu pula dengan gerakan dakwah ativis perempuan, keterlibatan dan partisipasi secara aktif dibeberapa sektor publik dan organisasi sosial telah memberikan warna baru terhadap proses rekonstruksi sosial masyarakat muslim. Pola ini dapat dilihat dari relasi hubungan antara laki-laki perempuan yang semakin baik, maju dan berdaya. Relasi hubungan ini berupa relasi pendidikan, ekonomi, sosial, budaya dan keagamaan. Perempuan dalam relasi pendidikan, melalui aktivitasnya mampu melahirkan critical education, pada aspek ekonomi menghasilkan evolusi pemenuhan kebutuhan ekonomi, dalam bidang politik memainkan peran strategis dalam counter of social, dalam bidang budaya memberikan perubahan paradigma nasioanal berbasis nilai lokal budaya perempuan yang 
lebih feminis partisipatif, dalam aspek keberagamaan mewujudkan pengembangan pemahaman teks normatif atas nilai ajaran agama yang dapat dimanfaatkan merubah isu-isu ketidakadilan dan kesetaraan perempuan di sektor publik (Saefuddin, 2000:69-70; Faqih, 2000:64).

\section{Metodologi Penelitian}

\section{Jenis dan Pendekatan Penelitian}

Kajian ini berupaya mendeskripsikan peran strategis aktivis perempuan dalam membentuk kesadaran beragama perempuan miskin kota di Banyumanik Semarang. Metode yang digunakan adalah deskriptif kualitatif dengan pendekatan psiko-fenomenologi. Deskriptif karena memaparkan secara detail apa saja peran strategis aktivis perempuan, menggunakan pendekatan psiko-fenomenologis karena dalam melaksanakan perannya, aktivis perempuan banyak menggunakan sentuhan psikologis dalam memaknai fenomena keberagamaan para perempuan miskin berserta proses penghayatan dan pelaksanaan ajaran agamanya.

\section{Teknik Pengambilan Data}

Data penelitian diperoleh dengan menggunakan Indept Interview dan Dokumentasi. Sedangkan pengambilan sampel menggunakan teknik purposive sampling (Muhajir, 1991:146). Untuk keperluan Validitas dan Reliabilitas Data menggunakan teknik trianggulasi (Sugiyono, 2007:337).

\section{Analisis}

\section{Makna Agama Bagi Perempuan Miskin Kota}

Agama merupakan sistem kepercayaan yang dianut para pemeluknya sesuai hakekat penciptaan, diwariskan secara turun temurun. Pemahaman keberagamaan seperti ini menguatkan pendapat Ali dan Munaf yang menyatakan bahwa agama lahir sebagai warisan turun menurun yang diikat status sosial (Ali, 1971:4; Munaf, 1996:2). Namun pada sebagaian masyarakat miskin, agama dipahami sebagai salah satu bentuk identitas sosial yang tercantum dalam Kartu Tanda Penduduk (KTP). Makna lain agama dalam 
pandangan komunitas miskin kota sebagai jalan mendapatkan kebahagiaan hidup. Agama merupakan bentuk kepasrahan dan kepatuhan terhadap kekuatan ghaib, proses memperoleh ketenangan batin, mendapatkan ketenangan, kebahagiaan, kesejahteraan sesuai harapkannya. Pengertian ini sesuai dengan temuan Hasanah (2004:49) yang menyatakan bahwa beragama menjadikan masyarakat mencapai kesejahteraan dan ketenangan hidup, sehingga seluruh problem kehidupan dapat dicarikan solusinya.

Beragama pada perempuan miskin Banyumanik dipahami sebagai formalitas kebutuhan hidup sosial, artinya beragama menjadi syarat administratif dan harus dimiliki warga yang tinggal di wilayah tertentu,tercatat dalam Kartu Tanda Penduduk (KTP). Warga yang tidak memiliki identitas keagamaan (Islam) di KTP, tidak memiliki hak menempati daerah tersebut. Berdasarkan keterangan dari ibu W, untuk dapat menempati wilayah tertentu, pertanyaan utama diajukan berkaitan dengan agama, asal dan pekerjaan. Masyarakat miskin Banyumanik secara demografis berasal dari masyarakat urban Solo dan Yogyakarta dan secara teologis memiliki fanatisme kuat terhadap perkembangan agama Islam, dan mereka yang dapat menunjukkan identitas formal keislaman, cenderung memiliki kemudahan ijin tinggal di wilayah tersebut. Hal inilah yang kemudian melahirkan pemahaman berbeda dan cenderung keliru mengenai makna agama bagi perempuan miskin di sekitar wilayah Banyumanik.

Pemaknaan agama yang keliru mengakibatkan rendahnya kesadaran perempuan miskin kota dalam menjalankan praktik ritual beserta sistem nilai yang berlaku dalam ajaran agama. Hal ini tentunya memerlukan upaya tepat dalam rangka membentuk kesadaran beragama perempuan miskin, sehingga terbentuk pemahaman positif terhadap ajaran agama, dan selanjutnya dapat mengoptimalkan segala potensi dalam mencapai kebahagiaan hidup yang dicita-citakan.

\section{Kiprah Aktivis Perempuan Nurul Jannah}

Aktivis perempuan Nurul Jannah telah memainkan peran strategis dalam membentuk dan meningkatkan kesadaran beragama perempuan miskin kota, hal ini ditunjukkan dengan semakin meningkatnya kualitas kesadaran beragama dalam setiap aspeknya 
yaitu aspek system nilai, sikap dan cara pandang positif dan terbuka, serta konsistensi nilai moral tinggi. Adapun kiprah aktivis Perempuan dapat dilihat dari pola kegiatan lembaga dakwah komunitas melalui tiga kegiatan unggulan yaitu, unit kegiatan kerja dan usaha utama, perantara dan bimbingan.

Unit kegiatan kerja dan usaha utama merupakan kiprah yang lebih berorientasi pada kegiatan syiar/tabligh. Fokus utama kegiatan utama mencapai pemahaman wawasan keislaman dan penanaman nilai-nilai ajaran agama. Para aktivis berperan memaiknak peran sebagai da'i, pendamping, fasilitator dan pembimbing anggota ataupun perempuan binaan. Secara umum unit kegiatan kerja dan usaha utama ini bergerak dalam kelompok majelis ta'lim yang secara intens menyelenggarakan kegiatan ceramah, diskusi, penyuluhan agama dan pendidikan berbasis masjid dan mushala. Unit kegiatan perantara merupakan salah satu bentuk kegiatan dakwah bi al-hal melalui aksi sosial dan tindakan nyata seperti mendirikan lembaga pendidikan Islam, kerja bakti, mendirikan bangunan keagamaan, penyantunan masyarakat secara ekonomis atau bahkan acaraacara hiburan keagamaan, bazaar murah, bantuan kebutuhan ekonomis, penyelenggaraan bakti sosial, menggali kreativitas dan semangat kerja binaan. Sejak berdirinya LDK Nurul Jannah, para aktivis perempuan berinisiatif mendirikan lembaga pendidikan qur'an yang awalnya menyatu dengan bangunan masjid utama. Pada perkembanganny LDK Nurul Jannah telah melaksanakan pendidikan qur'an di TPQ al-Hikmah. Aktivitas penyantunan dan pemberian bantuan kebutuhan ekonomis rutin dilaksanakan setiap tiga bulan sekali dan pada even hari besar agama Islam. LDK Nurul Jannah juga secara periodic menyelenggarakan pekan kreativitas perempuan binaan yang memiliki keterampilan mengkreasikan aneka produk makanan tradisional sebagai salah satu kegiatan pemberdayaan guna mengangkat potensi ekonomi keluarga.

Kegiatan bimbingan merupakan bentuk kegiatan irsyad Islam yang bertujuan mensosialisasikan ajaran Islam, sehingga mad'u atau binaan memiliki pemahaman yang positif terhadap ajaran agama dan selanjutnya ada kemauan dan kesadaran untuk menghayati dan mengamalkan ajaran agama secara konsistean. Aktivis Nurul Jannah merupakan kelompok sosial keagamaan yang sangat memperhatikan 
masalah bimbingan agama bagi para perempuan miskin baik anggota maupun binaannya. Bimbingan dilaksanakan baik secara individual maupun kelompok di setiap akhir pekan. Bimbingan individu dilakukan door to door, guna mengetahui kondisi dan situasi mentalekonomi binaan, sehingga dengan program bimbingan tersebut para perempuan miskin mampu secara mandiri menyelesaikan problem pemenuhan kebutuhan materi dan spiritualnya secara mandiri dan bertanggung jawab. Bimbingan kelompok dilakukan di masingmasing kelompok yang beranggotakan 3-4 anggota dengan seorang pendamping secara bergantian.

\section{Peran Strategis Aktivis Perempuan Nurul Jannah al-Firdaus}

Untuk meretas peran strategis para aktivis perempuan, diperlukan suatu lembaga atau komunitas gerakan yang dapat mengusung tema pemberdayaan dan pengembangan potensi komunitasnya secara makro. Peran strategis aktivis perempuan dalam lembaga sosial atau gerakan sosial tertentu dapat berupa peran utama, perantara dan peran pembimbing (Clements, dkk., 2002:106). Peran strategis ini banyak diadopsi dan dimainkan oleh para aktivis perempuan muslim di Lembaga Dakwah Komunitas (LDK).

Nurul Jannah al-Firdaus adalah salah satu lembaga dakwah komunitas yang ada di wilayah Banyumanik memainkan peran strategis ini. Secara kelembagaan Nurul Jannah al-Firdaus merupakan sub bagian dari LDK al-Hikmah. LDK Nurul Jannah al-Firdaus dalam wacana publik seringkali dipersepsikan sebagai organisasi sosial keperempuanan dan melakukan gerakan dakwah (jama'ah majelis taklim) yang mendasarkan seluruh aktivitas kegiatannya pada pelayanan sosial perempuan, seperti pengelolaan Taman Pendidikan Anak Usia Dini (TPAUD) gratis bagi keluarga miskin dan binaan, memprakarsasi penyantunan sosial bagi perempuan miskin, anak yatim dan terlantar, memprakarsai kredit usaha syari'ah. Sedangkan dalam kerangka gerakan dakwah, LDK Nurul Jannah al-Firdaus aktif melakukan pengajian rutin setiap tiga kali setiap bulannya, membina dan mengelola Taman Pendidikan al-Qur'an yang diprioritaskan pada kemampuan baca tulis al-Qur'an, praktik sholat, ibadah, dan pengetahuan agama Islam. LDK Nurul Jannah melaksanakan seluruh aktivitas kegiatannya dengan mendasarkan 
pengembangan kemampuan atau potensi perempuan dan secara integral menyelenggarakan pendampingan dan pembinaan keagamaan pada komunitas perempuan miskin disekitar bantaran sungai wilayah Banyumanik. Untuk menjalankan aktivitasnya, LDK Nurul Jannah memiliki unit kegiatan kerja dan usaha utama, perantara dan bimbingan. Unit kegiatan utama LDK Nurul Jannah berupa aktivitas kegiatan majelis ta'lim. Unit kegiatan perantara dilakukan melalui unit aksi sosial. Sedangkan kegiatan bimbingan berupa unit pendidikan dan pengembangan pengajaran baca tulis al-Qur'an.

\section{Unit kegiatan utama (majelis ta'lim) LDK Nurul Jannah}

Keberadaan unit majelis ta'lim ini ditujukan untuk memberikan pemahaman dan pendampingan pengetahuan keagamaan dan praktik ibadah para jama'ah dan peserta dampingan (perempuan miskin). Kegiatan yang dilakukan meliputi pengajian bulanan, pengajian mingguan, dan pendampingan harian. Pengajian bulanan biasanya dilakukan pada awal minggu pertama setap bulan dengan menghadirkan ustadz-ustadzah baik dari dalam maupun luar LDK. Tema pengajian bervariasi disesuaikan dengan kebutuhan dan prioritas pengembangan pemahaman keislaman anggota dan dampingan. Pengajian ini selain merupakan ceramah keagamaan, juga mendemonstrasikan kecakapan dan keterampilan baca tulis al-Qur'an para anggotanya sebagai upaya untuk menunjukkan dan mengevaluasi perkembangan kemampuan dan kecakapan baca tulis al'Qur'an yang telah diikuti anggota dan binaannya. Secara kualitas, keberadaan majelis ta'lim ini memberikan alternatif pengembangan kemampuan kognitif dan psikomotorik para anggotanya dalam mengembangkan dan memberdayakan potensi keberagamaan para anggota dan binaan. Penelitian ini dikuatkan dengan pandangan Kusmanto (2011:24) yang menyatakan bahwa keberadaan majelis ta'lim sebagai sebuah gerakan dakwah secara positif membantu pemerintah dalam memberikan pemahaman keagamaan yang bernilai positif dalam semua segi kehidupan (perorangan, keluarga, kelompok, negara) secara berjama'ah menjadi berkualitas dan berperadaban tinggi. 


\section{Unit Perantara}

Kegiatan perantara dilakukan dalam bentuk aksi sosial. Kegiatan ini khusus melaksanakan berbagai kegiatan sosial sebagai wujud kepedulian sosial terhadap anggota dan perempuan miskin binaan. Bentuk nyata dari aksi sosial ini meliputi penyantunan fakir, miskin, dan anak yatim (diprioritaskan bagi para janda dan perempuan miskin, serta yatim piatu), dan kegiatan bakti sosial (donor darah, penyediaan pasar murah di Hari Besar Islam (HBI)). Aksi ini secara sosial memberikan kontribusi positif dalam mengurangi beban kemiskinan masyarakat khususnya para janda, perempuan miskin dan nak yatim piatu. Nilai strategis dari adanya aksi sosial ini adalah mampu meningkatkan kepedulian sesama perempuan dalam mengurangi beban hidup dan membudayakan hidup berbagi dengan orang lain (Susanto, 2012:32 ).

\section{Unit kegiatan bimbingan}

Unit kegiatan bimbingan dalam praktiknya melakukan pendidikan dan pengembangan pengajaran keislaman dan baca tulis al-Qur'an. Kegiatan bimbingan bertujuan memberikan pemahaman keislaman dan menghapuskan buta baca tulis al-Qur'an anggota dan perempuan binaan. Pelayanan pendidikan dilakukan oleh ustadzah LDK profesional dan alumni TPQ al-Hikmah. Penelitian ini senada dengan pandangan Choliq (2012:26) yang menyatakan bahwa dalam rangka mengembangkan pendidikan Islam yang berkualitas tinggi, maka perlu didukung dengan manajemen, kekuatan strategi pembelajaran, sarana prasarana pendidikan dan kekuatan sumber daya profesional yang memiliki komitmen tinggi terhadap perkembangan dan inovasi strategi pendidikan Islam. Sumber daya profesional, dan handal dapat diciptakan dari kualitas para alumninya, dan selanjutnya diberdayakan dengan seoptimal mungkin sebagai kekuatan identitas dalam pendidikan Islam. Lebih lanjut Choliq menyebutkan bahwa potensi sumberdaya manusia yang diperlukan dalam pendidikan Islam pada hakekatnya mengembangkan prinsip buman dignity komunitas sendiri, sehingga mereka merasa dihormati, dihargai dan benar-benar dibutuhkan sebagai pendidik profesional. 
Selain pembinaan wawasan keislaman dan pengajaran alQur'an, LDK Nurul Jannah aktif melakukan pendampingan dan bimbingan personal. Bimbingan personal ditujukan untuk memberikan dukungan dan kepedulian secara intens dimasing-masing binaan. Kegiatan bimbingan menggunakan prinsip kegiatan irsyad Islam, melakukan bimbingan sebagai upaya internalisasi ajaran agama, sehingga para perempuan miskin kota lebih mengetahui, memahami dan mengamalkan ajaran agama secara mandiri, sebagai suatu kebutuhan ruhaniah yang harus dipenuhi. Lahir kesadaran untuk mau dan peduli dalam mengamalkan ajaran agama secara bertanggung jawab.

\section{Pembentukan Kesadaran Beragama Perempuan Miskin oleb Aktivis Perempuan}

Kesadaran beragama merupakan aspek penting yang harus dimiliki manusia, karena dengan kesadaran beragama tinggi menghasilkan pribadi yang berkualitas lahir dan batin. Untuk dapat mencapai kesadaran beragama tinggi dibutuhkan upaya serius dan strategis, dengan menggunakan tema-tema efisiensi dan efektivitas diri melalui pelibatan peran komunitas yang memiliki kedekatan baik secara sosial maupun emosional. Kesadaran beragama yang terbentuk dari suasana sosial-emosional kondusif menghasilkan pembentukan kesadaran tinggi optimal, karena melahirkan dinamika psikologis seperti perasaan terbuka, dekat, menimbulkan kesan menyengakan, persaudaraan dan saling kepercayaan. Kondisi ini selanjutnya dapat dimanfaatkan untuk menghasilkan fungsi terapi bagi individu, sehingga mereka dengan kerelaan hati merubah pemahamannya, tertarik dan terjadi perubahan perilaku secara mandiri dan bertanggung jawab.

Pembentukan kesadaran beragama perempuan miskin kota lebih difokuskan pada aspek sistem nilai, sikap dan cara pandang, serta konsistensi perilaku. Pembentukan kesadaran beragama yang dilakukan aktivis perempuan nurul Jannah al Firdaus menggunakan kerangka dasar kekuatan gerakan dakwah komunitas perempuan yang meliputi kegiatan utama dalam bentuk syiar/Tabligh, kegiatan bimbingan melalui unit pendidikan dan pengembangan pengajaran baca tulis al-Qur'an. Sedangkan kegiatan perantara dilakukan melalui unit aksi sosial. 


\section{Peran Strategis kegiatan utama}

LDK Nurul Jannah melakukan aktivitas pembentukan kesadaran beragama perempuan miskin kota dengan sistem syiar/ tabligh Islam dalam forum majelis ta'lim. Sistem ini dilakukan mengikuti pola pengajian rutin yang dilakukan oleh LDK Nurul Jannah alFirdaus. Pada unit kegiatan ini, para perempuan dibekali dengan ceramah pengajian mengenai materi-materi umum ajaran agama, seperti akidah, syari'ah, dan akhlak setiap minggu (setiap hari jum'at). Para aktivis memantau perkembangan penguasaan wawasan keislaman para perempuan miskin secara intens dan periodik. Selain itu para aktivis melakukan pendampingan kepada 3-4 perempuan binaan, dalam rangka memberikan kekuatan dan dukungan kepada binaannya agar mereka dapat memahami seluruh materi ajaran dengan baik. Fokus dari kegiatan utama ini adalah terbentuknya kesadaran beragama. Aspek kesadaran beragama melalui kegiatan syiar dan tabligh (majelis ta'lim) lebih pada kesadara menghadirkan sistem nilai. Aspek sistem nilai ini meliputi kemampuan memahami dan menghayati ajaran agama, serta memiliki kemampuan dalam merefleksikan hati nurani dalam menghadirkan nilai moral ajaran agama dalam kehidupan sehari-hari, melakukan instrospeksi diri, mengevaluasi diri, menginternalisasikan nilai dan moral ajaran agaman, dan selanjutnya meningkatkan ketakwaan serta keimanan.

Menurut Munti'ah (2012) pada semester kedua tahun 2012 kelompok binaannya telah mampu menghadirkan semangat keberislamannya dengan baik, masing-ma sing individu mulai dapat mereformasi pemahaman agama yang selama ini telah dipahami. Mereka telah memiliki pemahaman mengenai kewajiban-kewajiban apa saja yang harus dilakukan sebagai makhluk beragama, mulai ada kesadaran untuk menjalankan shalat lima waktu, mulai paham dengan bacaan shalat, mulai mengerti dengan kondisi yang tidak seharusnya mereka lakukan dimasa lalu. Sementara menurut Hj. Ningrum semangat ini diwujudkan dengan kerelaan binaan mengikuti kegiatan pengajian, melaksanakan praktik ibadah shalat lima waktu, dalam setiap aktivitas selalu membaca doa, mendorong anak-anaknya melakukan shalat dan belajar al-Qur'an, dan kehidupan mereka sudah mengalami perubahan dan selalu bersemangat dalam menghadirkan nilai-nilai keberislaman. Yang 
paling menggembirakan lagi ada kemandirian para perempuan ini untuk mulai menjalin relasi sosial yang lebih baik dengan lingkungan sekitar, mereka lebih humanis, menghadirkan sikap toleransi dan hormat menghormati kepada orang lain.

Aspek kedua dari kesadaran beragama adalah sikap dan cara pandang yang positif tentang ajaran agama. Para aktivis Nurul Jannah al-Firdaus selalu berupaya memberikan keteladanan dalam menghadirkan sikap dan cara pandang yang positif. Hal ini dibuktikan dengan adanya kesadaran dari para perempuan miskin untuk memandang dirinya bagian dari komponen masyarakat, yang selalu harus menjunjung tinggi semangat kebesamaan, menjalin hubungan yang harmonis dengan lingkungannya, mengembangkan kehidupan yang berkualitas dan selalu memandang segala permasalahan dengan cerdas, sehingga secara mandiri mereka mampu menyelesaikan seluruh problem yang dihadapi dengan mulus. Keteladanan ditunjukkan para aktivis Nurul Jannah dengan menempatkan binaannya sebagai teman dan saudara. Hal ini memberikan dampak psikologis yang positif bagi perempuan binaan sehingga mereka merasa dihargai, diterima dan selanjutnya mampu memandang dirinya sebagai bagian komunitas yang berhak dihormati, disayangi, digauli dan yang pasiti diterima lingkungannya dengan baik. Keteladanan dalam dakwah islamiyah merupakan metode tradisional yang sampai saat ini masing diunggulkan (Kusmawan, 2009:19). Dengan keteladanan seorang mad'u lebih mudah dalam melakukan penyesuaian sosial melalui proses identifikasi, imitasi dan simpati (Gerungan, 1988:54-55).

Aspek ketiga dalam pembentukan kesadaran beragama adalah konsistensi perilaku. Seorang dikatakan memiliki kesadaran beragama positif apabila mereka selalu menghadirkan konsistensi perilaku dalam kehidupannya. Konsistensi perilaku diwujudkan adanya kesesuaian antara lisan, ucapan dan perbuatan. Secara kualitas, para perempuan binaan aktivis Nurul Jannah memiliki tingkat konsistensi dalam berperilaku baik. Hal ini dibuktikan dari semakin meningkatnya kesadaran mereka untuk selalu menghadiri setiap acara dan kegiatan yang dilakukan LDK nurul Jannah, dalam pengembangan kualitas dirinya, para perempuan miskin ini telah konsisten dan rutin melaksanakan shalat jama'ah di masjid ataupun mushala, 
aktif menghadiri pengajian yasin dan pertemuan warga. Dalam hubungan sosial juga terbentuk kesadaran yang tinggi untuk lebih peduli lingkungan, menjaga kesehatan dan mulai ada kesadaran membuang sampah pada tempatnya sehingga lingkungan yang tadinya kumuh menjadi lebih tertata, tumpukan sampah mulai berkurang, dan kesehatan mulai lebih diperhatikan. Konsistensi perilaku merupakan salah satu aspek penting dalam perwujudan kesadaran diri.

Menurut Matta dalam Amin, dkk., (2005:35) konsistensi perilaku menempati posisi penting dalam perkembangan kesadaran diri. Hal ini menjadi tolak ukur tingkat kesadaran diri, karena aspek konsistensi ini merupkan aspek yang secara kualitas dan kuantitas dapat dicapai dan diamati secara langsung. Semakin konsisten perilaku seseorang maka seluruh aspek dari kesadaran diri seperti sistem nilai dan sikap dan cara pandang telah tercapai. Pendapat sama dikemukakan oleh Huijbers (2000:128), yang menyatakan bahwa konsistensi perilaku pada diri individu merupakan akumulasi dari sistem nilai dan sikap atau cara pandang positif mengenai agamanya. Orang yang memiliki konsistensi perilaku secara otomatis memiliki sistem nilai dan sikap atau cara pandang baik sehingga segala potensi hadir ke dalam kehidupan dan selanjutnya akan menampilkan citra diri unggul.

Keterlibatan aktivis perempuan nurul Jannah, dalam pembentukan kesadaran beragama komunitas perempuan miskin di Banyumanik telah memberikan warna sendiri, dan mampu menemukan alternatif pengembangan metode pendekatan peningkatan keberagamaan yang jauh lebih humanis. Untuk memberikan efek positif bagi perubahan perilaku keberagamaan masyarakat tertentu, maka metode, model dan pendekatan harus berbasis pada kebutuhan dan kondisi sasaran dampingan, sehingga timbul kemandirian, susana kemitraan sebagai wujud pengalaman empirik masyarakat (Diktis Islam, 2008:59). Kondisi ini didukung dengan keterlibatan lembaga dakwah dalam mengawal keberagamaan masyarakat yang berdampak pada terbangunnya respon emosional positif, perubahan pengetahuan, keterampilan, sikap, dan selanjutnya mampu menimbulkan community empowerment (Diktis Islam, 2008:88). 


\section{Peran Strategis unit Bimbingan melalui Pendidikan dan Pengajaran}

Bidang pendidikan dan pengajaran dalam sistem pendidikan Islam merupakan aspek yang penting karena pendidikan pada hakekatnya merupakan pemberdayaan manusia dalam menjalani kehidupan sekaligus untuk memperbaiki masa depan (Mansur, 2004:1). Pada unit pendidikan dan pengajaran LDK Nurul Jannah al-Firdaus menekankan pada penguasaan baca tulis al-Qur'an. Fokus pendidikan ini dilakukan karena keprihatinan para aktivis melihat kenyataan masyarakat muslim merupakan komunitas mayoritas, namun masih berada dalam bayangan buta baca tulis al-Qur'an. Untuk keperluan itu maka prioritas utama LDK Nurul Jannah menghilangkan buta baca tulis al-Qur'an yang diselenggarakan pada pengelolaan TPQ al-Hikmah. Dalam pengeloaannya, TPQ al-Hikmah melaksanakan pendidikan bagi anak dan perempuan (jama'ah perempuan dan ibu yang mengantarkan anak didik). Pendidikan al-Quran dilaksanakan setiap hari pada jam 14.00 sampai dengan 15.30. Pendidikan al-Qur'an anak-anak meliputi baca tulis al-Qur'an, tajwid, gharib al-Qur'an, hafalan juz amma, bacaan shalat, fikih, dan akhlak. Sementara bagi para perempuan lebih ditekankan pada penguasaan dan keterampilan baca tulis al-Qur'an.

Dalam melaksanakan pendidikan, terdapat emat tenaga profesional yang melakukan pendidikan terpadu. Tiga orang melaksanakan pendidikan bagi anak, dan seorang bertugas melaksanakan pendidikan bagi ibu dan orang tua pengantar anak didik. Pendampingan bebas buta baca dan tulis al-Qur'an juga diberikan kepada perempuan binaan aktivis Nurul Jannah. Bagi perempuan binaan, pelaksanaan pendidikan dan pengajaran tidak disentralkan di TPQ al-Hikmah, hal ini dimaksudkan untuk menjaga aspek psikologis dan emosional para anggota binaan, seperti rasa minder, malu dan merasa terpinggirkan dari komunitas lainnya. Pelaksanaan pendidikan dilakukan di lingkungan tempat tinggal perempuan binaan, yang dilakukan setiap dua kali seminggu. Pemilihan waktu ini didasarkan pada pertimbangan kesesuaian waktu yang dapat dilakukan oleh anggota binaan diluar aktivitas rutin mereka. Awalnya para anggota binaan tidak menunjukkan respon positif dengan program bebas buta baca tulis al-Qur'an, banyak diantara mereka menolak didampingi belajar. Merasa tidak 
bisa, kurang pandai, tidak paham, sulit sampai tidak ada waktu menjadi alasan utama. Tapi dengan kegigihan dari para aktivis, para binaan mulai memiliki kemauan untuk melaksanakan program tersebut. Secara umum pelaksanaan pendidikan delakukan secara bersama, berkelompok dan jama'ah. Hal ini dilakukan mengingat SDM pengajar terbatas.

Namun dengan sistem ini justru memberikan dampak positif karena menjadikan pendidikan lebih semangat dan ramai. Pada awal semester dua 2012, para anggoa telah berhasil menyelesaikan pemahaman terhadap huruf hija'iyah baik yang tunggal maupun dirangkai. Tingginya minat dan kesadaran anggota binaan ditunjukkan dengan semangat serta kemauan berjuang tinggi dari para anggota binaan. Kondisi ini merupakan awal pembentukan kesadaran beragama yang ditunjukkan oleh perempuan binaan. Mereka mulai menyadari pentingnya membaca al-Qur'an, sehingga timbul semangat untuk semakin mahir membaca dan menulis alQur'an. Pendidikan dengan menggunakan pendekatan kelompok ternyata memiliki implikasi psikologis berupa fungsi terapi kepada anggotanya. Dikatakan oleh Afiatin, dkk., kekuatan kelompok pada penyelenggaraan pendidikan secara psikologis membentuk dinamika psikologis yang berfungsi terapi sehingga akan melahirkan tema efektivitas dan efisiensi pemahaman pada kelompok tersebut (Afiatin, dkk., 1999:28). Dinamika psikologis itu berupa suasana pertemanan, persahabatan, sehingga melahirkan kepercayaan para anggota kelompoknya untuk berperan aktif dalam perubahan pemahaman kearah lebih baik (Dixon \& Glover, 1984:322).

\section{Peran Strategis Perantara melalui Aksi Sosial}

Aksi sosial merupakan kegiatan praktis yang secara nyata berkaitan dengan peran dan kepedulian sosial kepada sesama. Upaya ini merupakan wujud emiris gerakan sadar sosial yang banyak dikembangkan misionaris sebagai kekuatan utama proses kristenisasi di Indonesia. Aksi sosial dalam ajaran Islam merupakan aplikasi dimensi kerahmatan yang harus dikembangkan melalui aktivitas dakwah Islam dalam konteks tathwir melalui pengembangan, pemberdayan kehidupan dan ekonomi masyarakat. Secara sederhana, aksi sosial merupakan bentuk transformasi 
ajaran Islam melalui amal shaleh, dan kegiatan sosial lainnya (kusmawan, 2009:38; Ahmad, 1996:21; Enjang, 2009:51). Menurut Kusmanto (2011:175) aksi sosial dalam dakwah Islam merupakan pola dakwah sebagai bentuk kepedulian terhadap persoalan sosial umat, bentuk eksistensi gerakan dakwah komunitas, yang selanjutnya dapat dimanfaatkan sebagai sarana pencitraan positif tentang keberadaan LDK, terakui keberadaan dan kontribusinya. Sementara itu Susanto (2012) menyebutkan bahwa aksi sosial merupakan salah satu metode yang berorientasi pada kegiatan praktis operasional bersifat sosial sebagai upaya memberikan solusi kebutuhan sosial masyarakat dan selalu dibarengi pemenuhan kesejahteraan ekonomis (Susanto, 2012:122).

Salah satu peran strategis tersebut juga diperankan oleh LDK Nurul Jannah al-Firdaus dengan melaksanakan berbagai aksi sosial secara intens. LDK Nurul Jannah al-Firdaus yang didominsi aktivis perempuan, telah menempatkan aksi sosial sebagai salah satu strategi untuk menarik dan membentuk kesadaran beragama perempuan binaannya. Aksi sosial dilakukan dalam bentuk kegiatan penyantunan sosial (pembagian zakat, penyantuan fakir miskin dan anak yatim, penyelenggaraan pasar murah, bantuan sembako secara rutin dan pemberian bantuan pendidikan bagi anak yatim piatu). Secara psikologis aksi sosial ini terbukti mampu menarik perhatian perempuan binaan dan masyarakat untuk aktif melakukan kegiatan yang direncanakan, memberikan dampak psikologis yang begitu luar biasa pada perubahan sikap dan perilaku jama'ah dan binaan Nurul Jannah yang lebih sesuai ajaran agama.Perubahan itu juga dapat dilihat dari antusiasme jama'ah dan perempuan binaan untuk melaksanakan seluruh program yang direncanakan. Dari dua puluh lima perempuan binaan, didapatkan 19 orang telah memiliki komitmen tinggi menjalankan ritual ibadah yang selama ini telah dilupakan dan ditinggalkan. Untuk dapat melihat implikasi pembentukan kesadaran beragama melalui aksi sosial ini, akan dijelaskan dengan menggunakan aspek dari kesadaran beragama.

Pertama berkaitan dengan aspek sistem nilai. Dengan aksi sosial yang rutin diselenggarakan oleh para aktivis perempuan Nurul Jannah, memberikan makna tersendiri bagi para perempuan miskin binaan. Pembagian zakat, penyantuan fakir miskin dan anak yatim, 
penyelenggaraan pasar murah, bantuan sembako secara rutin dan pemberian bantuan pendidikan bagi anak yatim piatu menunjukkan tingkat kepedulian para aktivis dalam mewujudkan kesejahteraan dan pemenuhan kebutuhan ekonomi yang mereka butuhkan. Kondisi ini membuat para perempuan binaan merasa diperhatikan, dilindungi dan merasa menjadi bagian dari masyarakat yang tidak tersekat oleh kelas sosial masyarakat tertentu. Makna lain dari aksi sosial ini menjadikan mereka lebih bisa menerima keadaannya sebagai bagian dari komunitas masyarakat, sehingga membentuk siksp optimis, percaya diri dan selalu semangat untuk melakukan interaksi dengan lingkungannya. Makna lain melahirkan penerimaan diri yang positif, sehingga secara tidak langsung dapat membentuk kesadaran beragama mereka dengan menempatkan dirinya sebagai bagian komunitas yang tidak perlu dibedakan dan dideskriminasikan. Dengan terbentuknya penerimaan secara sosial, berarti telah terbentuk pemahaman mengenai penghayatan terhadap ajaran agamanya, internalisasi nilai-nilai ajaran agama dan pelaksanaan nilai aturan norma.

Aspek kedua kesadaran diri adalah sikap dan cara pandang positif. Aksi sosial yang dilakukan para aktivis telah membentuk sikap dan cara pandang kehidupanyang jauh lebih tertata dan diliputi semangat untuk maju dalam rangka mencapai kesejahteraan hidup. Para perempuan binaan telah memiliki sikap dan cara pandang untuk menghadirkan semangat dalam memenuhi kebutuhan hidup, semangat dalam memainkan peran sosialnya, serta memiliki dorongan yang tinggi dalam memperjuangkan kesejahteraannya. Kondisi ini menunjukkan bahwa kesadaran beragama para perempuan binaan telah terbentuk.

Aspek ketiga adalah konsistensi perilaku. Para aktivis Nurul Jannah cukup berhasil dalam membangun konsistensi perilaku perempuan binaan melalui aksi sosial. Konsistensi perilaku ini diwuudkan dengan kerja keras para binaan mempelajari dan mengembangkan kemampuannya dalam memahami ajaran agamanya. Secara bertahap para aktivis juga mulai menanamkan kepedulian dari para perempuan binaan untuk menyisihkan sebagian pendapatannya untuk beramal shalih. Para perempuan binaan perlahan-lahan telah berpartisipasi aktif mengeluarkan zakat, membantu anggota lain yang masih membutuhkan. Kemampuan menghormati dan menghargai 
orang lain juga telah dilaksanakan, sehingga kesenjangan sosial dengan mebeda-bedakan status sosial tidak lagi terjadi. Ini merupakan hal positif yang perlu dikembangkan dalam rangka menciptakan suasana kehidupan sosial yang sejahtera, bahagia dan setara.

\section{Kesimpulan}

Kesadaran beragama merupakan sikap mental yang harus dimiliki oleh setiap individu, untuk mengarahkan dirinya dalam mengembangkan potensi kemanusiaan untuk kesejahteraan dan kebahagiaan hidupnya. Pada beberapa komunitas miskin kota kesadaran beragama nampaknya tidak dapat dicapai dengan otimal. Hal ini dikarenakan adanya pemahaman keliru berkaitan dengan pemahaman konsep dasar agama, sehingga menimbulkan implikasi kemalasan dan ketidaksadaran dalam melaksanakan nilai-nilai ajaran agamanya. Kehadiran para aktivis perempuan Nurul Jannah dalam komunitas masyarakat miskin kota telah menunjukkan eksistensinya sebagai lembaga dakwah komunitas yang begitu memiliki perhatian pada pengembangan aspek keberagamaan perempuan miskin kota. Secara sistematis dan terstruktur para aktivis perempuan ini menunjukkan kiprahnya dalam membentuk kesadaran beragama perempuan miskin kota di wilayah Banyumanik. Adapun bentuk peran strategisnya dapat dilihat dari kemampuan para aktivis menyentuh seluruh aspek dari kesadaran diri yaitu aspek sistem nilai, sikap dan cara pandang positif serta konsistensi perilaku yang diintegralkan dalam gerakan dakwah Islam meliputi kegiatan utama dalam bentuk syiar/ tabligh, kegiatan bimbingan melalui pembimbingan (individual dan kelompok), pendidikan dan pengembangan pengajaran baca tulis al-Qur'an dan kegiatan perantara dilakukan melalui unit aksi sosial. Hasil dari peran strategis ini secara nyata mampu membentuk kesadaran beragama khususnya dalam pelaksanaan praktik ritual agama, semangat dan daya juang menerapkan nilai-nilai ajaran agama dan secara bertahap mampu memberdayakan potensi sosial keagamaan perempuan miskin kota untuk mewujudkan kesejahteraan dan kebahagiaan hidup.

\section{Daftar Pustaka}

Abidin, Masoed. 1999. Gerakan Dakwah Bangun Negeri. Jakarta: Gema Insani Press. 
Amin, Munirul, dkk., 2005. Psikologi Kesempurnaan. Yogyakarta: Arruz Media

Alfiatin, dkk. 1999. Meningkatkan Percaya diri melalui Konseling Kelompok. Jurnal Psikologi. No. 6, Th. III: 28-47

Aziz, Jumaah Amin Abdul. 2005. Fiqh Dakwah: Studi Analisis Berbagai Prinsip Dan Kaidah Yang Harus Dilakukan Dalam Dakwah Islamiyah. Jakarta: Intermedia.

Aziz, Moh. Ali, (ed.). 2009. Dakwah Pemberdayaan Masyarakat Paradigma Aksi Metodologi. Yogyakarta: LkiS Pelangi Aksara.

Bustaman, Hanna Djumhana. 1995. Integrasi Psikologi dan Islam: Menuju Psikologi Islami. Yogyakarta: Pustaka Pelajar.

Charles Tilly \& McAdam. 2001. Dynamic of Contention. Cambridge: Cambridge University Press.

Choliq, Abdul. Strategi Pengembangan Kualitas Pendidikan Islam di Indonesia. 2012. Jurnal At-Taqaddum: Jurnal Peningkatan Mutu Keilmuan dan Kependidikan Islam. Vol. 2, No. 2: 15-30

Collin, Elisabeth. "The Struggle for Political Reform in South Sumatra". dalam Autonomy and Desintegration in Indonesia. Damien Kingsbury dan Harry Aveling (eds.). 2003. London dan New York: Routledge Curzon, Vol. 9, No. 2: 157-176

Dixon DN., \& Glover J.A. 1984. Counseling: A Problem solving Approach. New York: Jhon Willey.

Dokumen Progres Report LDK Nurul Jannah al-Firdaus. 2011-2012. Semarang. Elisabeth S. Clements \& Martin D. Hughes. 2002. Recovering Past Protest: Historical Research on Social Movement. Minnesota: University of Minnesota Press.

Fakih, Mansour, dkk., 2000. Membincang Feminisme: Diskursus Gender Perspektif Islam. Surabaya: Risalah Gusti.

Gea, Antonius Atosokhi. 2002. Relaksasi dengan Diri Sendiri, Jakarta: Elex Media Komputindo.

Hasanah, Hasyim. 2004. Pengaruh Konsep Diri Dalam Meningkatkan Sikap Religius Remaja. Skripsi tidak dipublikasikan. IAIN Walisongo Semarang.

Hasanah, Hasyim. 2008. Pengaruh Kesadaran Diri dan Kematangan Beragama dalam Meningkatkan Komitmen Organisasi Karyawan RSUD Tugurejo Semarang. Tesis. tidak dipublikasikan. IAIN Walisongo Semarang.

Hasanah, Hasyim. 2011. Dewasakah Kita dalam Beragama? (Sebuah kajian Psikologi Agama). Makalah diskusi dosen. Devisi Labda. Fakultas Dakwah Semarang. 
Huijbers, Teo. 2000. Manusia Merenungkan Dirinya Sendiri. Yogyakarta: Kanisius

Hurlock, E.B. 1991. Psikologi Perkembangan: Suatu Pendekatan sepanjang Rentang Kehidupan. (terj.), Jakarta: Erlangga.

Jalaluddin. 2007. Psikologi Agama: Memahami Perilaku Keagamaan dengan Mengaplikasikan Prinsip-prinsip Psikologi. Jakarta: PT. Rajawali.

Jamhari \& Ismatu Ropi. 2003. Citra Perempuan dalam Islam. Jakarta: PT. Gramedia Pustaka Utama.

Kusmanto, Thohir Yuli. 2011. Gerakan Dakwah di Kampus Riwayatmu Kini. Lemlit: IAIN Walisongo

Kusmawan, Aep, dkk., 2009. Dimensi Ilmu Dakwah. Bandung: Widya Padjajaran.

Macherdrawaty, Nanik dan Agus Ahmad Syafei. 2001. Pengembangan Masyarakat Islam. Bandung: Rosdakarya.

McGlen, E Nancy \& Karen O'Connor. 1995. Women, Politic, And American Society. New Jersey: Prentice Hill.

Miles, Mathew B. dan A. Michael Huberman. 1992. Analisis Data Kualitatif: Buku Sumbertentang Metode-metode Baru. Jakarta: UI Press.

Monk, Robert C., dkk. 1979. Exploring Religious Meaning. London: Prentice Hall International Inc.

Pedoman Program Pengabdian Kepada Masyarakat. 2009. Direktorat Pendidikan Tinggi Islam. Direktorat Jenderal Pendidikan Islam, Departemen Agama RI.

Rakhmat, Jalaluddin. 2001. Islam Aktual. Bandung: Mizan.

Sahid, Hussain. 1977. Iqbal's Concept of Personal Identity. M. Ma'ruf (ed.). Lanhore Islamic: Books Service.

Shomali, M. Ali. 2002. Mengenal Diri. Jakarta: Lentera

Sitomorang, Abdul Wahib. 2007. Gerakan Sosial: Studi Kasus Beberapa Perlawanan. Yogyakarta: Pustaka Pelajar

Subhan, Arif, dkk. 2003. Partisipasi Publik Perempuan. Jakarta: PT. Gramedia Pustaka Utama.

Susanto, Dedy. 2012. Aktivitas Dakwah MTA: Studi Pola Strategi dan Metode Gerakan Dakwah MTA. Lemlit: IAIN Walisongo.

Soedarsono, Soemarno. 2000. Penyemaian Jati Diri, Jakarta: Elex Media Komputindo.

Syadzali, Faruq. 2012. Pola Strategi Management Penyuluhan Agama Islam dalam Meningkatkan Sikap Religius Santri Program Khusus Penyuluh Agama. Kementerian Agama RI: Diktis Islam. 